\title{
THE UNTAPPED POTENTIAL OF PLANT THIN CELL LAYERS
}

\author{
Research note \\ Jaime TEIXEIRA DA SILVA ${ }^{1 *}$, Maria Maddalena ALTAMURA ${ }^{2 *}$, Judit DOBRÁNSZKI $^{3 *}$ \\ ${ }^{1}$ Retired \\ ${ }^{2}$ Sapienza - Università di Roma, Rome, Italy \\ ${ }^{3}$ Research Institute of Nyíregyháza, University of Debrecen, Hungary \\ Received: September 2015; Accepted: November 2015
}

\begin{abstract}
Thin cell layers (TCLs), which contain a small number of cells or tissues, are explants excised from different organs (stems, leaves, roots, inflorescences, flowers, cotyledons, hypocotyls/epicotyls, and embryos). After almost 45 years of research, this culture system has been used for several monocotyledonous and dicotyledonous plants of commercial importance, and for model plants. The limited amount of cells in a TCL is of paramount importance because marker molecules/genes of differentiation can be easily localized in situ in the target/responsive cells. Thus, the use of TCLs has allowed, and continues to allow, for the expansion of knowledge in plant research in a practical and applied manner into the fields of tissue culture and micropropagation, cell and organ genetics, molecular biology, biochemistry, and development. Starting from a brief historical background, the actual and potential uses of the TCL system are briefly reviewed.
\end{abstract}

Key words: model plants; organogenesis; plant biotechnology; TCLs

\section{TCLs: a brief background}

The revolutionary finding by Tran Thanh Van (1973) that a tiny layer of pedicel epidermal cells of tobacco, the thin cell layers (TCLs), could lead to the formation of flowers, shoots, roots and callus, simply by manipulating the auxin to cytokinin ratio was truly an important event in plant tissue culture. TCLs serve as a simple, yet effective way to control the developmental pathway and organogenic outcome and provide, where tested, an effective way of mass producing clones of specific organs.

TCLs have been used for the effective tissue culture of several dozen plants with commercial importance, spanning model plants such as orchids (Teixeira da Silva 2013), tobacco, Arabidopsis thaliana (Della Rovere et al. 2013, 2015) or snapdragon, field crops (cereals, rape, rice) horticultural commodities (fruits, vegetables, ornamental plants), medicinal plants and herbs, and even forestry trees ( $\mathrm{Pi}$ nus sp.), and woody fruit plants, Citrus spp. and apple (Fig. 1) (Dobránszki \& Teixeira da Silva 2011;
Teixeira da Silva \& Dobránszki 2013). Yet, the lack of applications of such a simple model system for staple crops such as wheat or potato, or for a wider range of medicinally and pharmaceutically important species, or even to other woody tree species like sandalwood that may be facing extinction, suggests that the potential of this technique remains widely underexplored.

\section{TCLs: actual and potential uses}

Even though research is increasingly turning toward more complex molecular techniques, there is still a constant need to mass produce plant tissues or organs in a sterile and controlled in vitro growth environment. TCLs hold particular value where specific organs might be required for highly specialized experiments, such as the production of in vitro flowers (Teixeira da Silva 2013; Teixeira da Silva et al. 2014) to make anthers or stigmas available at any time, but which, under natural conditions, would be severely restricted to specific seasons. Such applica- 
tions can easily be envisioned for saffron, which uses only the stigmas for the food, flavor, and fragrance industries.

Compared with conventional explants, the use of TCLs for morphogenesis (organogenesis, xylogenesis, or somatic embryogenesis) may result in higher productivity due to lower levels of endogenous plant growth regulators in the TCL, more effective transport of the medium components to the target cells, earlier morphogenesis, or a higher ratio of the morphogenic cells compared to the total number of cells of the explant (Tran Thanh Van 2003).

In an unpublished experiment, transverse TCLs (tTCLs) of stem segments from in vitro apple shoots of cv. Freedom induced adventitious shoots when cultured on regeneration medium (defined in Dobránszki \& Teixeira da Silva 2011), containing $22.7 \mu \mathrm{M}$ thidiazuron (TDZ) and $1.07 \mu \mathrm{M} \alpha$-naphthaleneacetic acid (NAA). The number of regenerated shoots increased when stem tTCLs $(0.2-0.3 \mathrm{~mm}$ thick) were used and the number of shoots per stem tTCL was as much as 39\% higher than control stem explants (2-3 mm thick). Shoot initials were already well developed by the fourth week of regeneration on stem tTCLs cultured in light (L in Fig. 1). When stem tTCLs were cultured in light (L), the percentage of shoot-regenerating explants (i.e., regeneration percentage) increased 23\% more than tTCLs or control explants cultured in the dark (D) during the first three weeks of regeneration $(\mathrm{D}+\mathrm{L})$. Moreover, inverse orientation of stem tTCLs was more favorable than the normal orientation, resulting in 30\% higher regeneration. The number of shoots per regenerating explant $(0$ in $\mathrm{L}$ vs. 1.4-1.5 in D+L) was significantly lower on leaf tTCLs (Dobránszki \& Teixeira da Silva 2011) than on stem TCLs (2.1-2.5).

The use of Arabidopsis longitudinal TCLs (ITCLs) has assisted in the study of the genetic and hormonal control underlying adventitious root formation. Arabidopsis 1TCLs are formed by the stem inflorescence tissues external to the vascular system, i.e. uniseriate epidermis, three or four cortical layers, a monolayered endodermis, and one or two fiber layers. The formation of adventitious roots was induced by indole-3-butyric acid $(10 \mu \mathrm{M})$ plus kinetin $(0.1 \mu \mathrm{M})$ under continuous darkness for at least two weeks of culture. The explants were cultured horizontally, epidermal side up, and the adventitious roots appeared all along their surface and originated from a unique tissue, i.e., the stem endodermis (Falasca et al. 2004), by superimposed periclinal divisions and occurred at the same time of expansion and cell-to-cell separation events in the cortex (Fig. 2A). The endodermis periclinal derivatives either organize root meristemoids, further developing into roots (i.e., a rhizogenic response), or proliferate into superimposed callus-like layers with xylary clumps or strands (xylogenesis) (Fig. 2B) (Della Rovere et al. 2013, 2015). By using numerous mutants and transgenic lines it has been demonstrated that Arabidopsis plants form adventitious roots in planta starting from the pericycle of the hypocotyl, with no involvement of the hypocotyl's endodermis. Their formation involves auxin accumulation, and related gene expression, in the initiating cells, derived by periclinal and anticlinal divisions of the pericycle, and in the meristem cells of the primordium and mature root apex (Della Rovere et al. 2013, 2015). However, under the same hormonal treatment of ITCLs, the pericycle derivatives may be alternatively involved in ectopic xylary development (Della Rovere et al. 2015). The response in vitro of the ITCLs excised from the same mutant and transgenic lines allowed to understand that when the adventitious roots are formed by different founder cells in planta, the stem endodermal cells express the same genes, and hormonal control, necessary for their development in planta. This demonstrates that the founder tissue may not be a determinant for the correct development of an adventitious root. Interestingly, the use of ITCLs has also been useful for demonstrating that adventitious root formation and xylogenesis (Fig. 2B) originated from the stem endodermis and that these two developmental programs are inversely related, since the same programs take place in the pericycle in planta, with the same transcription factors involved in the initiation programs, and the same auxin influx carrier in their switching (Della Rovere et al. 2015). 


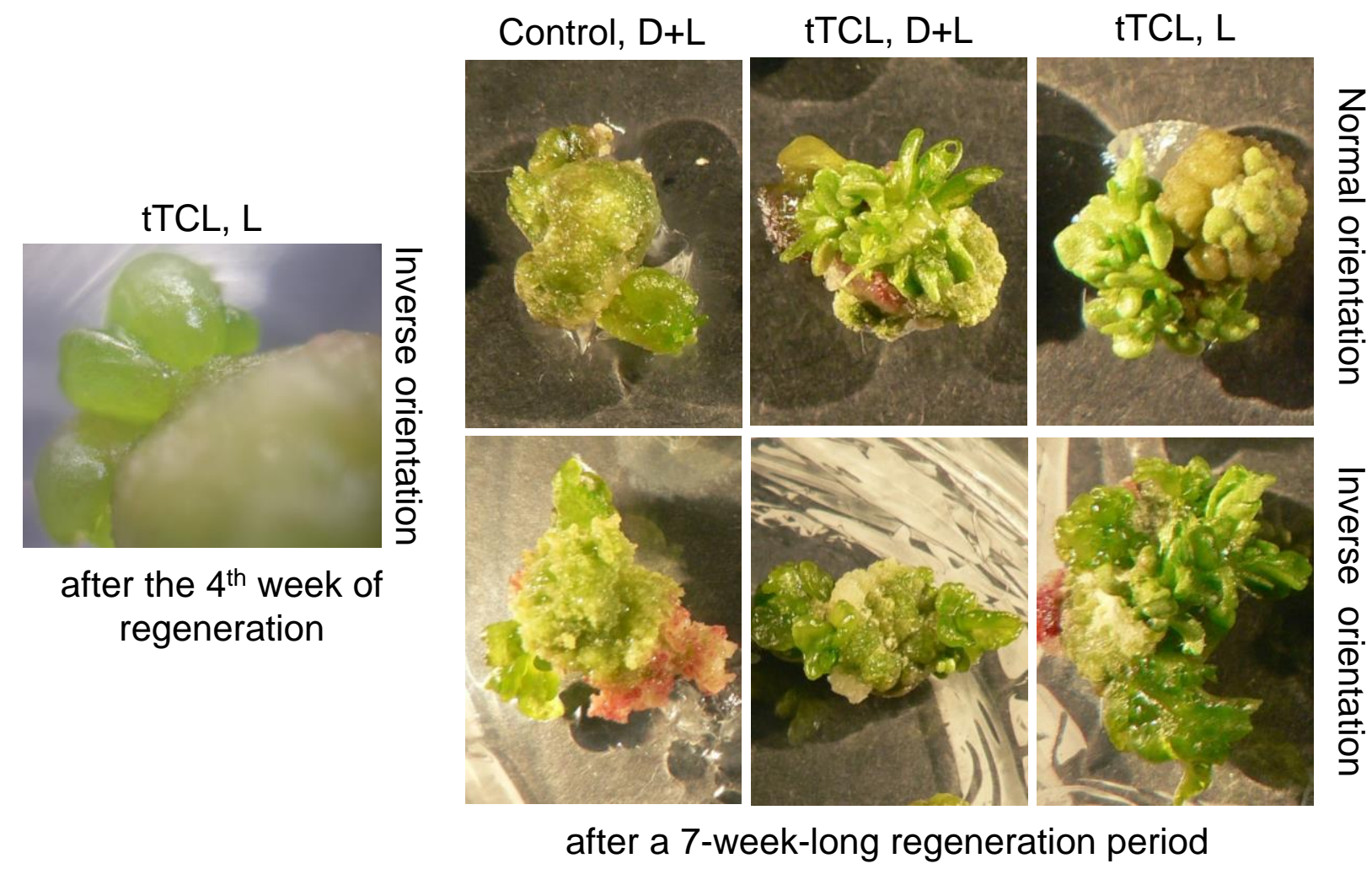

Fig. 1 Adventitious shoot initials from apple (Malus $\times$ domestica) 'Freedom' forming from stem transverse thin cell layers of in vitro shoots after 4 weeks in culture (left photo) and adventitious shoots after 7 weeks of regeneration (right photo plate)
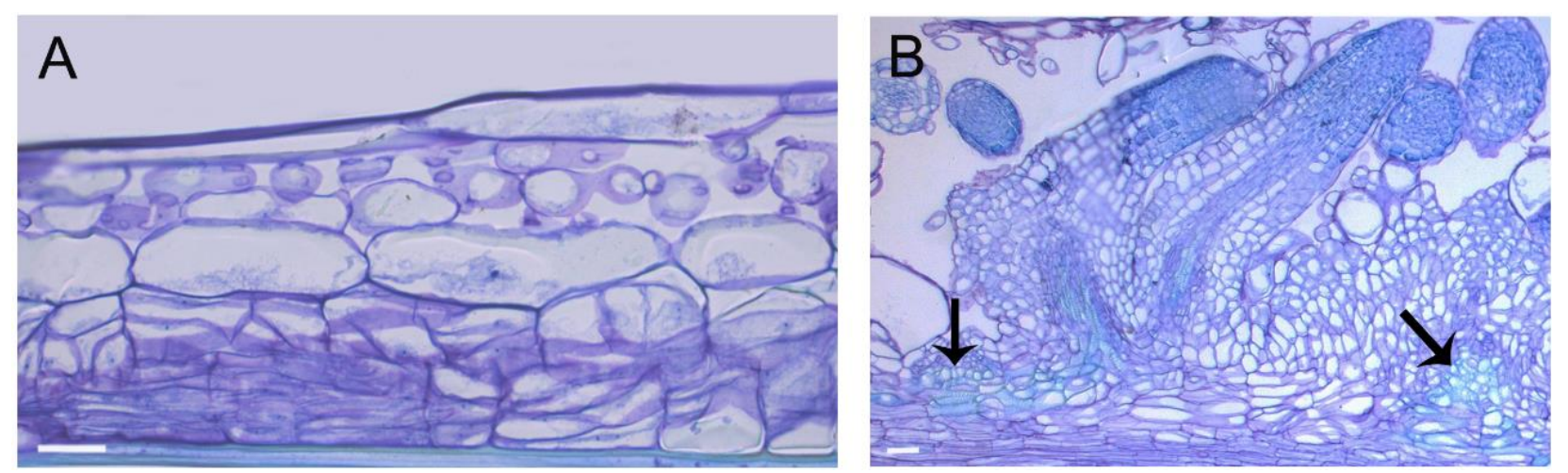

Fig. 2 Histological stages of adventitious root formation from Arabidopsis thaliana 1TCLs cultured with indole-3butyric acid $(10 \mu \mathrm{M})$ plus kinetin $(0.1 \mu \mathrm{M})$ under continuous darkness. A - superimposed layers of derivatives from the stem endodermis (lower part of the explant), and expanded and separated cells of the cortical layers (upper part of the explant) (day 5 of culture). B - Adventitious roots in longitudinal and cross-section at the end of culture (day 14). Some of them protrude from the explant. Superimposed cell layers of endodermal derivatives are shown in the lower part of the image with the roots arising from the outermost of these derivatives. Xylary cells in these derivatives (xylogenesis) are also visible (arrows). Radial longitudinal sections (bright-field images, toluidine blue staining). Scale bars $=30 \mu \mathrm{m}$ 
In addition, the secret to the developmental success of a TCL in vitro lies, not only in the tissue types it might incorporate, either by cutting transversally or longitudinally, but also in the area and volume of the explant itself. Using three horticultural crops (Cymbidium, apple, and chrysanthemum), the plant growth correction factor was used to extrapolate the productivity of a TCL relative to a conventional explant, indicating that even though the face-value organogenic outcome was less in TCLs than in conventional explants, once the size, shape, and volume of the explant were factored in, the productivity of the TCL was, in fact, several fold higher than a conventional explant (Teixeira da Silva \& Dobránszki 2014). This little known fact by many plant scientists, together with the smallest of developmental treasures, the TCLs, would serve the plant science community well, if applied more widely to a greater range of plant species. Finally, the use of TCLs in model species would serve to improve knowledge about the genetic control of plant development, and its plasticity, as the recent papers on Arabidopsis TCLs demonstrate (Della Rovere et al. 2013, 2015).

\section{TCLs: new developments}

TCLs continue to serve as a model cellular developmental system. Since our last reviews (Teixeira da Silva 2013; Teixeira da Silva \& Dobránszki 2013), eight studies that employed TCLs have emerged in the literature. The majority of these new studies targeted new plant species that had not yet tested the use of TCLs for in vitro regeneration, or mass propagation by organogenesis or somatic embryogenesis. These plants include three regional medicinal plants, i.e. ipecacuanha (Psychotria ipecacuanha Brot.) (Botero Giraldo et al. 2015), bulbous ceropegia (Ceropegia bulbosa Roxb.) (Dhir \& Shekhawat 2014), and Paris polyphylla Sm. (Raomai et al. 2015), an ornamental, Brasilidium forbesii (Hook.) Campacci (Gomes et al. 2015), an orchid (Teixeira da Silva 2014), Agave fourcroydes Lem., a plant used in the fiber industry (Monja-Mio \& Robert 2014), and Stevia rebaudiana Bertoni (Ramírez-Mosqueda \& Iglesias-Andreu 2015), used in the food industry. Moreover, TCLs were used as the regeneration system of choice for pyrethrum
(Tanacetum cinenariifolium, (Trev.) Sch. Bip) in Agrobacterium-mediated transformation (Mao et al. 2014). These studies attest to the continued importance of TCLs as a simple, yet effective model regeneration system for a wide range of plant species, including horticultural crops.

\section{REFERENCES}

Botero Giraldo C., Urrea Trujillo A.I., Naranjo Gómez E. J. 2015. Regeneration potential of Psychotria ipecacuanha (Rubiaceae) from thin cell layers. Acta Biológica Colombiana 20(3): 181-192. DOI: 10.15446/abc.v20n3.47354. (in Spanish with English abstract)

Dobránszki J., Teixeira da Silva J.A. 2011. Adventitious shoot regeneration from leaf thin cell layers in apple. Scientia Horticulturae 127: 460-463. DOI: 10.1016/j.scientia. 2010.11.003.

Della Rovere F., Fattorini L., D’Angeli S., Veloccia A., Falasca G., Altamura M.M. 2013. Auxin and cytokinin control formation of the quiescent centre in the adventitious root apex of Arabidopsis. Annals of Botany 112: 1395-1407. DOI: 10.1093/aob/mct215.

Della Rovere F., Fattorini L., D’Angeli S., Veloccia A., Del Duca S., Cai G., Falasca G., Altamura M.M. 2015. Arabidopsis SHR and SCR transcription factors and AUX1 auxin influx carrier control the switch between adventitious rooting and xylogenesis in planta and in in vitro cultured thin cell layers. Annals of Botany 115: 617-628. DOI: 10.1093/aob/mcu258.

Dhir R., Shekhawat G.S. 2014. In vitro propagation using transverse thin cell layer culture and homogeneity assessment in Ceropegia bulbosa Roxb. Journal of Plant Growth Regulation 33(4): 820-830. DOI: 10.1007/s00344-014-9432-2.

Falasca G., Zaghi D., Possenti M., Altamura M.M. 2004. Adventitious root formation in Arabidopsis thaliana thin cell layers. Plant Cell Reports 23: 17-25. DOI 10.1007/s00299-004-0801-3.

Gomes L.R.P., Franceschi C.D.B., Ribas L.L.F. 2015. Micropropagation of Brasilidium forbesii (Orchidaceae) through transverse and longitudinal thin cell layer culture. Acta Scientiarum - Biological Sciences 37(2): 143-149. DOI: 10.4025/actascibiolsci.v37i2.27276

Mao J., Zhou Y., Guo C.X., Xu H.L., Wang C.Y. 2014. An Agrobacterium - mediated transformation system 
from thin cell layer explants of pyrethrum (Tanacetum cinenariifolium). Acta Horticulturae 1035: 163-170. DOI: 10.17660/ActaHortic.2014.1035.19.

Monja-Mio K.M., Rober M.L. 2014. Direct somatic embryogenesis of Agave fourcroydes Lem. through thin cell layer culture. In Vitro Cellular \& Developmental Biology - Plant 49(5): 541-549. DOI: 10.1007/s11627-013-9535-7.

Ramírez-Mosqueda M.A., Iglesias-Andreu L.G. 2015. Direct organogenesis of Stevia rebaudiana Bertoni using thin cell layer (TCL) method. Sugar Tech. (in press). DOI: 10.1007/s12355-015-0391-0.

Raomai S., Kumaria S., Kehie M. Tandon P. 2015. Plantlet regeneration of Paris polyphylla $\mathrm{Sm}$. via thin cell layer culture and enhancement of steroidal saponins in mini-rhizome cultures using elicitors. Plant Growth Regulation 75(1): 341-353. DOI: 10.1007/s10725-014-9957-1.

Teixeira da Silva J.A. 2013. The role of thin cell layers in regeneration and transformation in orchids. Plant Cell, Tissue and Organ Culture 113: 149-161. DOI: 10.1007/s11240-012-0274-y.

Teixeira da Silva J.A. 2014. Response of hybrid Cymbidium (Orchidaceae) protocorm-like bodies to 26 plant growth regulators. Botanica Lithuanica 20(1): 3-13. DOI: 10.2478/botlit-2014-0001.

Teixeira da Silva J.A., Dobránszki J. 2013. Plant thin cell layers: a 40-year celebration. The Journal of Plant Growth Regulation 32: 922-943. DOI: 10.1007/s00344-013-9336-6.

Teixeira da Silva J.A., Dobránszki J. 2014. Dissecting the concept of the thin cell layer: theoretical basis and practical application of the Plant Growth Correction Factor. The Journal of Plant Growth Regulation 33: 881-895. DOI: 10.1007/s00344-014-9437-x.

Teixeira da Silva J.A., Kerbauy G.B., Zeng S-J., Chen ZL., Duan J. 2014. In vitro flowering of orchids. Critical Reviews in Biotechnology 34: 56-76. DOI: 10.3109/07388551.2013.807219.

Tran Thanh Van M. 1973. In vitro control of de novo flower, bud, root and callus differentiation from excised epidermal tissues. Nature 246: 44-45. DOI: 10.1038/246044a0.

Tran Thanh Van M. 2003. Thin cell layer concept. In: Nhut D.T., Van Le B., Tran Thanh Van K., Thorpe T. (Eds.) Thin Cell Layer Culture System: Regeneration and Transformation Applications. Kluwer Academic Publisher, Dordrecht, the Netherlands, pp. 1-16. DOI: 10.1007/978-94-017-3522-3_1. 